\title{
KAJ IAN ASPEK KEBERLANJUTAN PADA PENGELOLAAN PERIKANAN BUDIDAYA KERAMBA JARING APUNG DI WADUK CIRATA (JAWA BARAT)
}

\author{
Ani Widiyati*) dan Dietriech G. Bengen**) \\ *) Balai Penelitian dan Pengembangan Budidaya Air Tawar \\ Jl. Sempur No. 1, Bogor 16154 \\ E-mail:ani_widiyati@yahoo.co.id \\ *) Fakultas Perikanan dan IImu Kelautan Institut Pertanian Bogor \\ JI. Raya Darmaga, Kampus IPB Darmaga, Bogor 16680
}

(Naskah diterima: 28 Desember 2011; Disetujui publikasi: 16 Maret 2012)

\begin{abstract}
ABSTRAK
Kondisi Waduk Cirata (Jawa Barat) telah mengalami pencemaran berat, diduga akibat pengelolaan yang belum tepat, oleh sebab itu, diperlukan suatu pengelolaan waduk yang sesuai, dengan pengelolaan perikanan budidaya yang tepat agar berkelanjutan. Penelitian ini bertujuan untuk mengetahui aspek yang berpengaruh untuk keberlanjutan pengelolaan perikanan budidaya keramba jaring apung di Waduk Cirata (Jawa Barat). Metode penelitian dengan survai cepat (wawancara dengan pakar dan peninjauan lapang), analisis data dengan software Rapfish. Hasil penelitian memperlihatkan aspek ekologi merupakan aspek yang paling lemah (skor 22,29\%) untuk keberlanjutan pengelolaan Waduk Cirata. Aspek sosial budaya merupakan aspek terbesar (skor 57,37\%; yang merupakan modal utama dalam melakukan intervensi pada keempat aspek lainnya, yaitu aspek kelembagaan-kebijakan (skor 40,16\%), teknologi/ infrastruktur (skor 49,79\%), aspek ekonomi dan ekologi (skor 51,32\%).
\end{abstract}

KATA KUNCl: pengelolaan, keberlanjutan, waduk, keramba jaring apung

ABSTRACT: The study of sustainability aspects of cage culture fisheries management in Cirata Reservoir (West Java). By: Ani Widiyati and Dietriech G. Bengen

Cirata Reservoir conditions (West Java) have experienced severe pollution, allegedly caused by management that have not exact, therefore, required an appropriate reservoir management, including the proper management of aquaculture can be sustainable. This study aims to determine the aspects that affect the sustainability of the management of aquaculture in cageculture Cirata Reservoir (West Java). Research methods to rapidly survey (interviews with experts, reviewing the field), data analysis software Rapfish. The results show the ecological aspect is the weakest aspect in the management of sustainability Cirata Reservoir (22.29\%). Socio-cultural aspect is the largest point $(57.37 \%)$, which is the main capital of the intervention on the four aspects, namely, institutional-politica of aspects (40.16\%), technology/infrastructure (49.79\%), and the economic aspects (51.32\%).

KEYWORDS: management, sustainability, reservoir, cage culture 


\section{PENDAHULUAN}

Budidaya ikan dalam keramba jaring apung di Waduk Cirata telah memberikan keuntungan yang cukup besar, terbukti dari jumlah keramba jaring apung (KJA) di Waduk Cirata dari waktu ke waktu makin meningkat. Kegiatan budidaya ikan di Waduk Cirata termasuk ke dalam kegiatan budidaya intensif karena pakan ikan yang diberikan $100 \%$ adalah pakan buatan. Frekuensi pemberian pakan rata- rata tiga kali sehari bahkan lebih dengan pakan komersial yang mengandung protein tinggi (lebih dari $20 \%$. Melimpahnya limbah organik yang berasal dari sisa pakan diduga mengakibatkan Waduk Cirata menghadapi masalah yang cukup serius, antara lain proses sedimentasi yang tinggi dan penurunan kualitas perairan. Pertambahan jumlah KJA budidaya ikan di Waduk Cirata yang dimulai tahun 1987 sampai tahun 2002 semakin meningkat. Peningkatan jumlah KJA sampai tahun 1997 dapat meningkatkan produksi total ikan, tetapi mulai tahun 1998 peningkatan jumlah KJA tidak sejalan dengan peningkatan produksinya. Hal ini diduga karena kualitas air di Waduk Cirata yang mulai menurun setelah tahun 1997 sampai tahun 2002, serta akibat sering terjadinya kematian massal ikan budidaya akibat pencemaran dan terserang virus herpes (Prihadi et al., 2005).

Limbah dari aktivitas KJA di Waduk Cirata yang menumpuk di dasar perairan waduk telah menimbulkan dampak negatif baik terhadap lingkungan perairan maupun terhadap kelangsungan umur waduk dan kegiatan usaha perikanan. Sebagai contoh, adanya hujan terus- menerus atau gerimis apalagi diikuti dengan angin yang cukup kencang, akan berakibat pembalikan massa air dari dasar perairan ke perairan bagian atas, sehingga zat beracun yang sudah lama terakumulasi di dasar perairan terangkat ke atas. Peristiwa ini disebut dengan kejadian up welling yang mengakibatkan kematian massal pada ikan dalam KJA (Prihadi et al., 2005). Permasalahan yang dihadapi pada budidaya ikan dalam KJA di Waduk Cirata jika tidak ditangani secepatnya dapat berdampak pada ketidakberlanjutan kegiatan tersebut, oleh sebab itu, perlu dikaji aspek keberlanjutan pada kegiatan budidaya ikan di Waduk Cirata.

Sumberdaya perlu digunakan secara efisien untuk mencapai produksi optimal secara berkelanjutan dengan memelihara kestabilan dan menghindari eksploitasi sumberdaya yang berlebihan. Penilaian keberlanjutan memiliki beberapa tujuan yaitu dalam upaya untuk (1) mencapai efisiensi penggunaan sumberdaya, (2) mendorong pencapaian tujuan berkelanjutan, dan (3) mengembangkan landasan ilmiah mempunyai dasar ilmiah dalam menilai keberlanjutan suatu aktivitas pembangunan. Efisiensi penggunaan sumberdaya dimaksudkan untuk menjamin ketersediaan sumberdaya dalam jangka panjang dan lintas generasi serta menekan terjadinya konflik (Hassanshahi et al., 2008), mengoptimalkan jasa lingkungan dan pencapaian tujuan keberlanjutan pembangunan (Rammel et al., 2007). Penelitian ini bertujuan untuk membuat kajian aspek keberlanjutan pada pengelolaan perikanan budidaya KJA di Waduk Cirata (Jawa Barat).

\section{BAHAN DAN METODE}

Data yang dikumpulkan adalah data primer dan data sekunder. Data primer diperoleh dengan metode survai cepat dengan wawancara dan pengisian kuisioner oleh pakar. Data sekunder adalah data kegiatan keramba jaring apung, beban pencemar, daya dukung perairan, dan sumberdaya manusia. Pengolahan data menggunakan alat analisis Rap-fish yang merupakan teknik penilaian kinerja berbagai aspek yang mempengaruhi keberlanjutan suatu aktivitas (Pither \& Preischot, 2001). Pinter et al. (2005) menyatakan aspek keberlanjutan yang dinilai meliputi: ekologi, sosial budaya, ekonomi, dan kelembagaan. Setiap aspek keberlanjutan terdiri atas beberapa atribut yang merupakan variabel-variabel yang mempengaruhi ketersediaan sumberdaya. Atribut ditentukan berdasarkan hasil observasi kondisi Waduk Cirata saat ini, studi literatur, dan wawancara dengan para pakar.

Penilaian kinerja menggunakan pendapat pakar dan data sekunder dalam bentuk skala 0 sampai 2 atau 3 yang menunjukan kategori buruk sampai baik. Perubahan kinerja atribut ditunjukkan dengan nilai akar nilai tengah kuadrat Root Mean Square (RMS) pada sumbu $x$. Nilai RMS merupakan standar error yang bertujuan mengetahui nilai perubahan atribut saat terjadi perubahan kinerja dari suatu aspek keberlanjutan. Untuk mengevaluasi hasil penilaian atribut terhadap status pengelolaan waduk berkelanjutan, dilakukan simulasi Montecarlo. Simulasi Montecarlo dapat 
menunjukkan perkiraan tingkat kesalahan skor setiap atribut sehingga pengaruh kesalahan acak terhadap suatu proses dapat dievaluasi dan keakuratan koordinat dapat diprediksi. Status keberlanjutan yang ditunjukkan dengan perpaduan setiap aspek dengan nilai $0 \%$ sampai $100 \%$ ditampilkan dengan diagram layang. Apabila nilai indeks $>50 \%$ menunjukkan sistem 'berkelanjutan' dan sebaliknya jika nilai indeks 7 50\%

\section{HASIL DAN BAHASAN}

Adanya penilaian keberlanjutan memudahkan proses evaluasi. Landasan ilmiah penilaian keberlanjutan perlu dikembangkan karena memerlukan pemahaman ilmu lintas disiplin yaitu ilmu sosial, ekonomi, dan lingkungan (Hassanshahi et al., 2008). Penilaian keberlanjutan dilakukan oleh pengambil kebijakan seperti pemerintah daerah, pemerintah pusat, atau lembaga penelitian dan sebaiknya dilaksanakan secara terus- menerus, sehingga diperoleh informasi ilmiah terkait perkembangan pemanfaatan sumberdaya dan pola penggunaannya.

\section{Aspek Ekologi}

Penilaian aspek ekologi pada pengelolaan waduk berkelanjutan berbasis perikanan budidaya KJA merupakan penilaian terhadap atribut frekuensi kejadian up welling, tingkat kematian ikan, tingkat produksi ikan, tingkat pencemaran di daerah aliran sungai (DAS) di waduk, dan daya dukung perairan. Gambar 1 memperlihatkan atribut aspek ekologi yang sensitif terhadap kinerja pengelolaan waduk berkelanjutan yaitu frekuensi kejadian up welling, tingkat kematian ikan, tingkat produksi ikan, tingkat pencemaran di DAS, tingkat pencemaran di waduk dan daya dukung perairan, dengan nilai standar error atau nilai akar kuadrat nilai tengah (AKNT) masing- masing sebesar 11,16\% 3,17\% 5,12\% 5,71\% 5,82\% dan $1,37 \%$

Terjadinya frekuensi up welling ternyata merupakan atribut yang mempunyai AKNT yang terbesar yaitu 11,16\%yang berarti atribut ini sangat menentukan dalam keberlanjutan pengelolaan waduk tersebut. Hal ini diduga frekuensi up welling mengakibatkan kerugian material yang besar. Sejak tahun 1991, 1993, dan 1997 jumlah ikan yang mati di Waduk Cirata berturut- turut 34,5 ton; 29,2 ton; dan 209,3 ton (Krismono, 1999). Dalam sehari, jumlah ikan yang mati pasca terjadinya up welling mencapai 60 ton, atau kalau dirupiahkan setara Rp 500 juta. Data tersebut menunjukkan bahwa jumlah kerugian yang ditimbulkan oleh kematian massal ikan di Waduk Cirata dari tahun ke tahun kecenderungannya semakin meningkat. Data tersebut menunjukkan bahwa kondisi lingkungan Waduk Cirata terus memburuk (BPWC, 2003).

Menurut Garno (2002), up welling (pembalikan lapisan air) hanya terjadi pada waktu suhu permukaan air dan lapisan di dalamnya secara signifikan berbeda. Pada waktu suhu permukaan air turun, terjadi pada puncak musim hujan atau ketika suhu sangat dingin pada awal atau akhir musim kemarau, maka lapisan air dari dasar waduk naik dengan membawa zat beracun seperti $\mathrm{NH}_{3}, \mathrm{H}_{2} \mathrm{~S}$, dan $\mathrm{CO}_{2}$. Gas dan zat beracun itu terakumulasi dari proses pembusukan anaerob di lapisan bawah, terutama akibat sisa pakan dan kotoran ikan. Fenomena tersebut biasanya terjadi puncak musim hujan, yaitu pada bulan Januari- Februari atau pada akhir musim kemarau.

Untuk mengurangi dampak up welling di antaranya dengan mengurangi padat tebar ikan, memelihara ikan yang tahan terhadap kualitas air buruk (ikan catfish), serta penggunaan pakan ikan yang berkualitas dan ramah lingkungan. Pakan ramah lingkungan (telah berhasil diramu oleh ahli nutrisi Ikan di Universitas IImu dan Teknologi Kelautan Tokyo). Pakan ini dibuat dengan menambahkan asam sitrat atau amino acid- chelated (asam amino yang terikat dengan mineral seperti $\mathrm{Zn}, \mathrm{Mn}$, dan $\mathrm{Cu}$ ) sehingga jumlah unsur fosfor yang dilepas ke air menjadi menurun. Dengan menggunakan pakan ikan ini, jumlah unsur fosfor yang tertahan (terakumulasi) di dalam badan ikan meningkat sekitar 30\%untuk pakan yang ditambahkan asam sitrat atau $16,5 \%$ untuk pakan yang disuplementasi dengan amino acid-chelated. Penggunaan pakan ini juga berhasil menurunkan tingkat ekskresi nitrogen oleh ikan meskipun tidak begitu tinggi.

Khusus untuk masalah polusi amonia yang jauh lebih berbahaya daripada fosfat, barubaru ini telah dikembangkan strain ikan nila ramah lingkungan melalui pendekatan genetik. Dengan demikian amonia yang dikeluarkan dari badan ikan menjadi menurun, yaitu sekitar $30 \%$ 40\%lebih rendah daripada ikan biasa. 


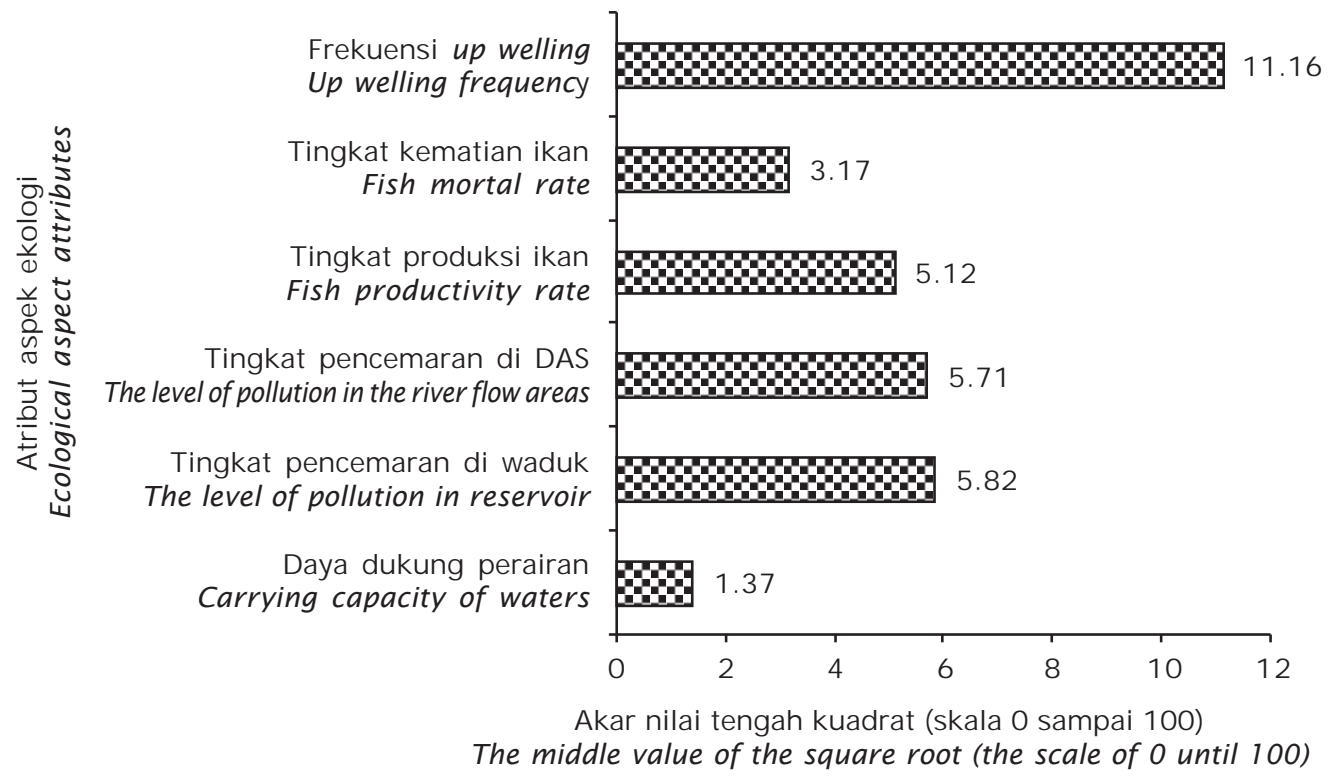

Gambar 1. Atribut aspek ekologi pada pengelolaan waduk berbasis perikanan budidaya berkelanjutan di Waduk Cirata (\%)

Figure 1. Ecological aspect attribute of management of reservoirs based on sustainable aquaculture in Cirata Reservoir's (\%)

\section{Aspek Ekonomi}

Penilaian aspek ekonomi pada pengelolaan waduk berbasis perikanan budidaya KJA berkelanjutan merupakan penilaian terhadap atribut peningkatan pendapatan asli daerah (PAD) dari usaha KJA, peningkatan pendapatan masyarakat, kemudahan pasar, harga jual produk, biaya produksi budidaya, biaya investasi KJA.

Gambar 2 menunjukkan atribut aspek ekonomi yang sensitif terhadap kinerja pengelolaan waduk berkelanjutan yaitu peningkatan PAD dari usaha KJA, peningkatan pendapatan masyarakat, kemudahan pasar, harga jual produk, biaya produksi budidaya, biaya investasi KJA, dengan nilai standar error atau nilai akar kuadrat nilai tengah (AKNT) masing- masing sebesar 3,12\% 4,09\% 0,58\% 2,94\%; 0,12\%; dan 1,35\% Peningkatan pendapatan masyarakat merupakan atribut yang mempunyai AKNT yang terbesar yaitu $4,09 \%$ yang berarti atribut ini sangat menentukan keberlanjutan pengelolaan waduk tersebut.

Dari hasil wawancara dengan masyarakat di sekitar wilayah Waduk Cirata, sebagian besar mereka mencari nafkah sebagai pembudidaya ikan baik di darat maupun di waduk, pembudidaya ikan, pedagang saprodi, pemilik warung di sekitar waduk, pengusaha transportasi di waduk. Masyarakat di wilayah waduk berharap keberadaan Waduk Cirata akan meningkatkan taraf hidup mereka dengan peningkatan pendapatan dari fungsi waduk seperti peningkatan hasil pertanian karena adanya irigasi yang lancar, peningkatan produksi ikan karena adanya lahan budidaya (perairan waduk), peluang pekerjaan baru lainnya seperti dari perdagangan saprodi pertanian dan budidaya ikan yang meningkat, rumah makan baik di pinggir maupun di tengah waduk, transportasi untuk mengangkut pakan dan ikan di darat maupun di perairan waduk.

\section{Aspek Hukum Kelembagaan}

Penilaian aspek hukum dan kelembagaan pada pengelolaan waduk berbasis perikanan budidaya KJA berkelanjutan merupakan penilaian terhadap atribut kebijakan pemerintah terhadap pembuangan limbah, penegakkan hukum, koordinasi dan implementasi pengelolaan KJA, dan kebijakan pemerintah tentang keberadaan KJA. Gambar 3 menunjukkan atribut aspek hukum dan 
Peningkatan PAD dari usaha KJA The increase of regional budget from cage culture

Peningkatan pendapatan masyarakat Income enhancement of the community

Kemudahan pasar The ease of market

Harga jual produk The selling price of the product

Biaya produksi budidaya The cost of cultivation production

Biaya investasi KJA The cost of cage culture infestation

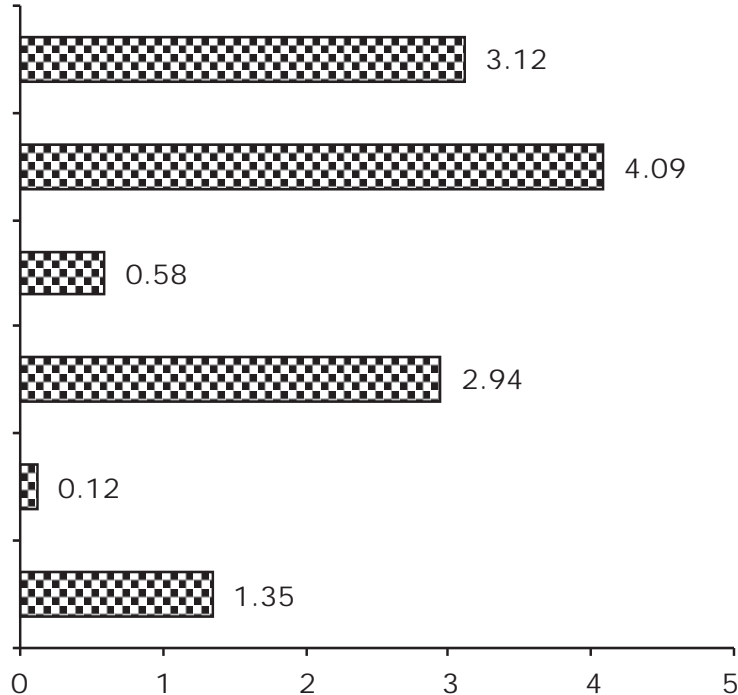

Akar nilai tengah kuadrat (skala 0 sampai 100)

The middle value of the square root (the scale of 0 until 100)

Gambar 2. Atribut aspek ekonomi pada pengelolaan waduk berbasis perikanan budidaya berkelanjutan di Waduk Cirata (\%)

Figure 2. Economical aspect attributes on the management of reservoir based on sustainable aquaculture in Cirata Reservoir's (\%)
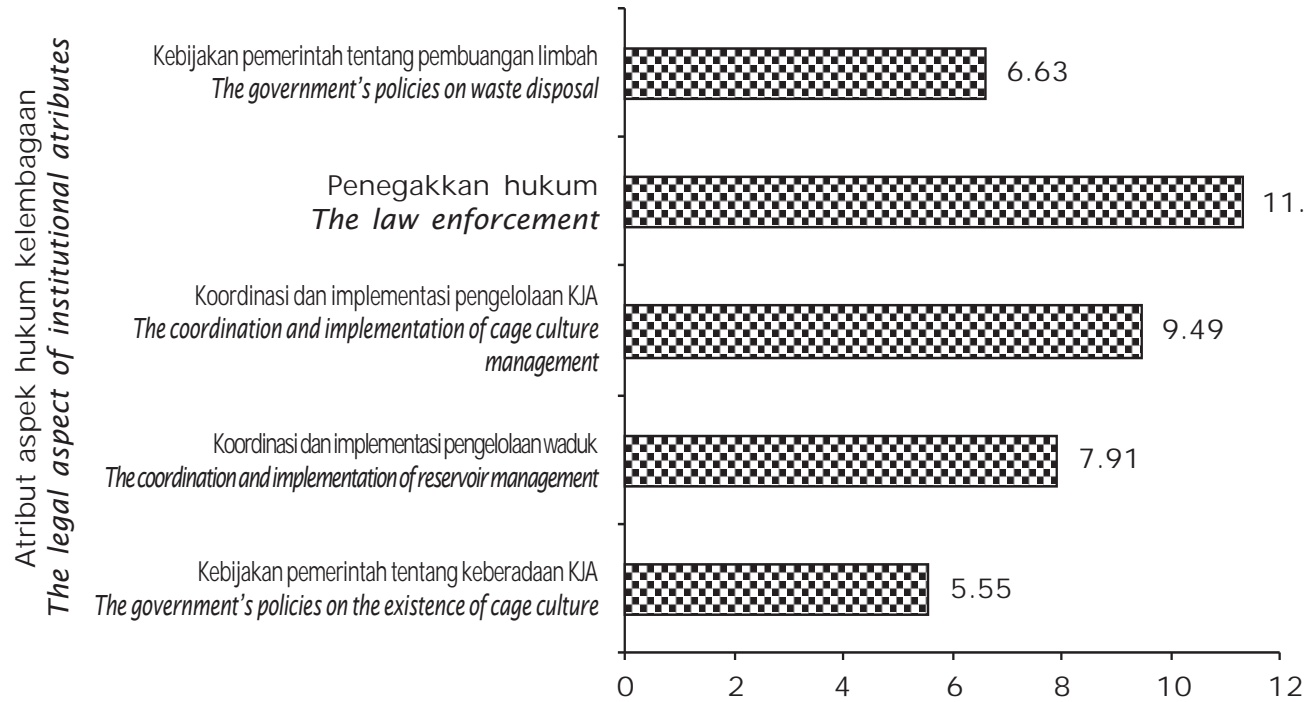

Akar nilai tengah kuadrat (skala 0 sampai 100)

The middle value of the square root (the scale of 0 until 100)

Gambar 3. Atribut aspek hukum dan kelembagaan pada pengelolaan waduk berbasis perikanan budidaya berkelanjutan di Waduk Cirata ( $\%$

Figure 3. Legal and institutional aspect attributes of reservoir management based on sustainable aquaculture in Cirata Reservoir's (\%) 
kelembagaan yang sensitif terhadap kinerja pengelolaan waduk berkelanjutan yaitu kebijakan pemerintah terhadap pembuangan limbah, penegakkan hukum, koordinasi dan implementasi pengelolaan KJA, dan kebijakan pemerintah tentang keberadaan KJA, dengan AKNT masing- masing sebesar $6,63 \% 11,34 \%$ 9,49\% 7,91\% dan 5,55\% Penegakan hukum merupakan atribut yang mempunyai AKNT yang terbesar yaitu 11,34\%yang berarti atribut ini sangat menentukan keberlanjutan pengeIolaan waduk tersebut.

Dalam suatu penegakkan hukum, sesuai kerangka Friedmann, hukum harus diartikan sebagai suatu isi hukum (content of law), tata laksana hukum (structure of law), dan budaya hukum (culture of law) sehingga penegakkan hukum tidak saja dilakukan melalui perundang- undangan, namun juga bagaimana memberdayakan aparat dan fasilitas hukum juga, yang tak kalah pentingnya adalah bagaimana menciptakan budaya hukum masyarakat yang kondusif untuk penegakkan hukum (Mutiari, 2005). Masyarakat harus senantiasa mendapatkan penyadaran dan pembelajaran yang kontinu. Maka, program penyadaran, kampanye, pendidikan, harus terus-menerus digalakkan dengan metode yang partisipatif. Akhirnya, penegakkan hukum harus memperhatikan keselarasan antara keadilan dan kepastian hukum. Tujuan hukum antara lain adalah untuk menjamin terciptanya keadilan (justice), kepastian hukum (certainty of law), dan kesebandingan hukum (equality before the law) (Mutiari, 2005).

Dalam hal ini penegakkan hukum yang harus dilakukan misalnya, penegakkan undang- undang keberadaan jumlah KJA di Waduk Cirata, keberadaan/ penempatan KJA pada zonasi yang tepat, pembuangan limbah industri, pertanian, dan peternakan ke perairan sungai khususnya ke DAS Citarum.

\section{Aspek Infrastruktur dan Teknologi}

Penilaian aspek infrastruktur dan teknologi pada pengelolaan waduk berbasis perikanan budidaya KJA berkelanjutan merupakan penilaian terhadap atribut kelas kesesuaian lahan, jenis ikan yang dibudidayakan, jumlah pakan, jenis pakan, padat tebar ikan, ketersediaan alat pendukung di $\mathrm{KJA}$, ketersediaan kapal untuk transportasi, dermaga untuk pengangkutan ikan, SPBU, dan aksesbilitas yang mudah ke lokasi budidaya. Gambar 4 menunjukkan atribut aspek infra-

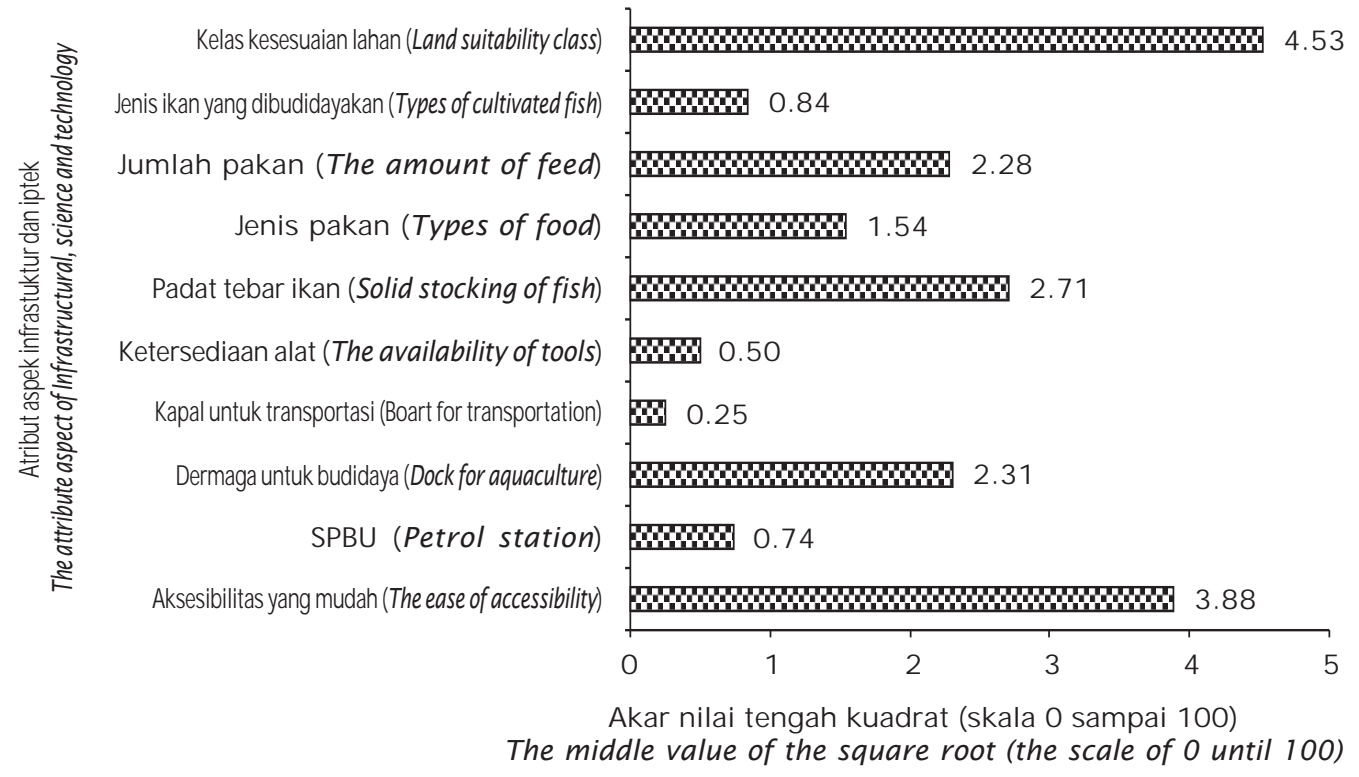

Gambar 4. Atribut aspek infrastruktur dan teknologi pada pengelolaan waduk berbasis perikanan budidaya berkelanjutan di Waduk Cirata (\%)

Figure 4. Infrastructural and technological aspect attributes of management reservoir based on sustainable aquaculture in Cirata Reservoir's (\%) 
struktur dan teknologi yang sensitif terhadap kinerja pengelolaan waduk berkelanjutan yaitu kelas kesesuaian lahan, jenis ikan yang dibudidayakan, jumlah pakan, jenis pakan, padat tebar ikan, ketersediaan al at pendukung di KJA, ketersediaan kapal untuk transportasi, dermaga untuk pengangkutan ikan, SPBU, dan aksesbilitas yang mudah ke lokasi budidaya, dengan AKNT masing- masing sebesar 4,53\% 0,84\% 2,28\% 1,54\% 2,71\% 0,50\% 0,25\% 2,31\% 0,74\% dan 3,88\% Kelas kesesuaian lahan merupakan atribut yang mempunyai AKNT yang terbesar yaitu 4,53\%yang berarti atribut ini sangat menentukan keberlanjutan pengelolaan waduk tersebut. Kesesuaian lahan yang tinggi diperlukan untuk keberlanjutan suatu kegiatan usaha. Kondisi perairan Waduk Cirata saat ini sudah tidak sesuai lagi untuk kegiatan budidaya ikan KJA, mengingat kondisi lingkungan perairan sudah memburuk (BPWC, 2008).

\section{Aspek Sosial Budaya}

Penilaian aspek sosial budaya pada pengelolaan waduk berbasis perikanan budidaya KJA berkelanjutan merupakan penilaian terhadap atribut dukungan Lembaga Swadaya Masyarakat (LSM) setempat, pendidikan sumberdaya manusia (SDM) pengelola waduk, tingkat SDM masyarakat, dan pengelola KJA. Hasil penelitian memperlihatkan AKNT masing- masing sebesar $4,65 \% 1,11 \%$ $3,42 \%$ dan $1,54 \%$ Dukungan LSM setempat merupakan atribut yang mempunyai AKNT yang terbesar yaitu 4,65\%yang berarti atribut ini sangat menentukan keberlanjutan pengelolaan waduk tersebut. Dukungan LSM merupakan suatu potensi yang perlu dimanfaatkan dan dikembangkan dengan melakukan kegiatan positif seperti membentuk kelompok tani dalam rangka pengelolaan waduk. Kelompok tersebut dapat berupa kelompok tani nelayan, kelompok pemerhati lingkungan yang bisa diajak untuk melaksanakan reboisasi hutan, dan lain- lain. Selanjutnya dilakukan sosialisasi kepada masyarakat, pelatihan, pembinaan, pembentukan kelompok/paguyuban, pembuatan kerja sama, pendampingan, dan memberikan bantuan dalam pengelolaan waduk. Gambar 5 memperlihatkan atribut sosial budaya pada pengelolaan waduk berbasis perikanan budidaya di Waduk Cirata.

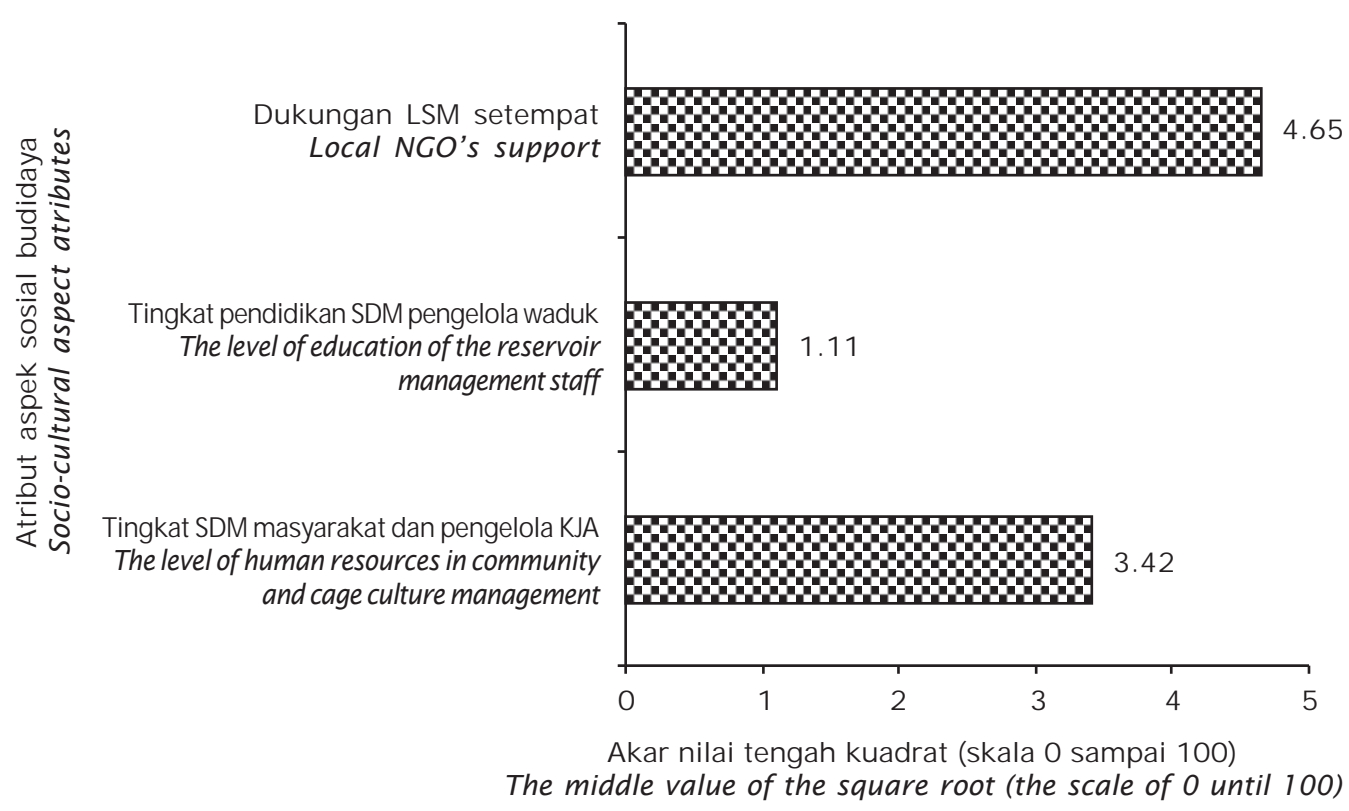

Gambar 5. Atribut aspek sosial budaya pada pengelolaan waduk berkelanjutan berbasis perikanan budidaya di Waduk Cirata (\%)

Figure 5. Socio-cultural aspect attributes in the sustainable reservoir management based on aquaculture in Cirata Reservoir's (\%) 


\section{Status Keberlanjutan Pengelolaan Waduk Berbasis Perikanan Budidaya Ikan}

Status keberlanjutan pengelolaan waduk berbasis perikanan budidaya merupakan keterpaduan penilaian aspek ekologi, ekonomi, sosial, teknologi/ infrastruktur, dan kelembagaan/kebijakan. Kelima aspek penentu tercapainya suatu pengelolaan waduk berkelanjutan saling terkait dan mempengaruhi yang ditunjukkan oleh diagram layang (Gambar 6). Selanjutnya Gambar 6 menunjukkan bahwa kondisi aspek ekologi merupakan aspek yang sangat lemah sehingga perlu ditingkatkan dalam pengelolaannya. Aspek ini perlu mendapat perhatian yang serius mengingat kondisi waduk sudah memprihatinkan seperti pendangkalan dan eutrofikasi (penyuburan unsur hara). Akibatnya keragaman ekologi akuatik waduk terancam, termasuk ikan- ikan yang dibudidayakan di KJA. Kualitas air baku waduk juga menurun dan mulai tercemar logam berat (Krismono, 1999).

Pendangkalan, eutrofikasi, dan turunnya kualitas air waduk diduga akibat DAS Citarum rusak dan intensifnya pengembangan KJA untuk meningkatkan produksi ikan. Kerusakan DASCitarum baik di hulu dan hilir diduga akibat pertumbuhan penduduk yang meningkat pesat, tidak bijaknya manusia dalam membuang limbah industri, peternakan, rumah tangga, dan pertanian, serta penyalahgunaan tata ruang. Tempat pembuangan akhir sampah Sarimukti di Cipatat, Kabupaten Bandung Barat, termasuk penyumbang limbah air lindi yang besar ke Waduk Cirata karena lokasi TPA sangat dekat dengan DAS Citarum (MSMAS, 2009).

Keberlanjutan aspek sosial budaya merupakan aspek terbesar (skor 57,37\%, yang merupakan modal utama dalam melakukan intervensi pada keempat aspek lainnya, yaitu aspek kelembagaan- kebijakan (skor 40,16\%), teknologi/ infrastruktur (skor 49,79\%), aspek ekonomi (skor 51,32\%), dan ekologi (skor $22,29 \%$. Dukungan LSM di sekitar wilayah perairan Waduk Cirata yang cukup besar dalam pengelolaan waduk, perlu dibina dan ditingkatkan oleh pemerintah. Dari hasil wawancara dengan masyarakat, mereka berpendapat bahwa Waduk Cirata adalah sumberdaya alam milik bersama yang harus dikelola bersama agar fungsinya berkeIanjutan. Sistem kerja sama antara warga di

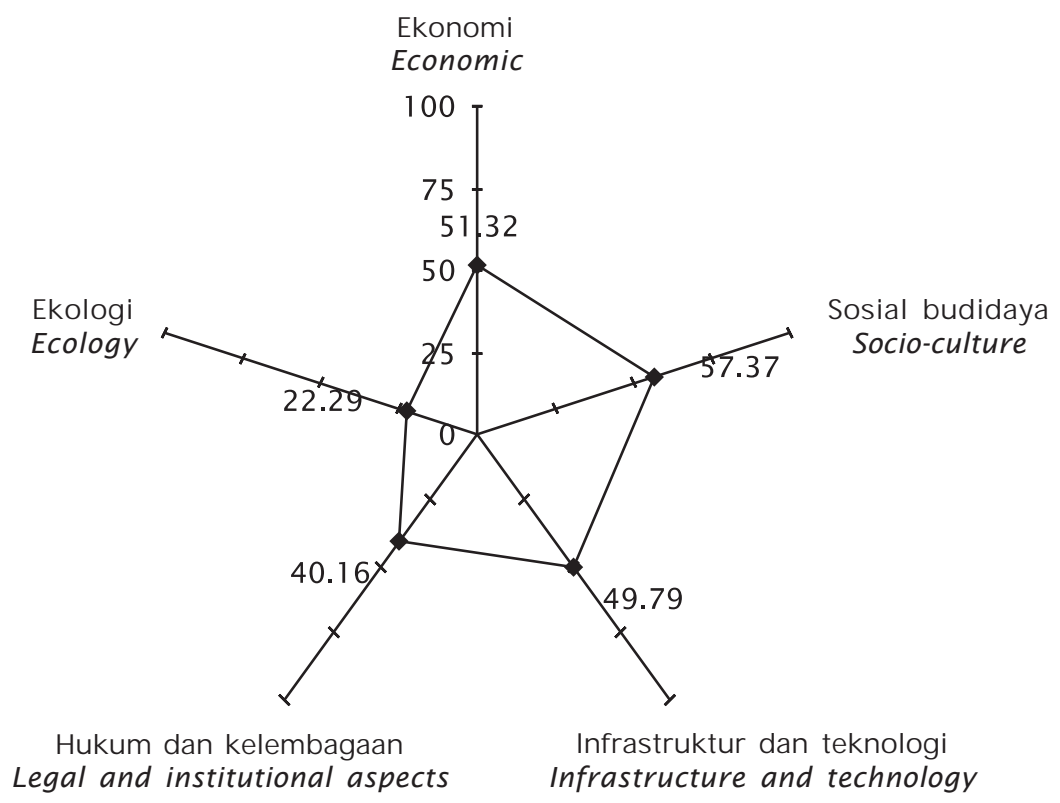

Gambar6. Status keberlanjutan pengelolaan Waduk Cirata berbasis perikanan budidaya kerambajaring apung (\%)

Figure 6. Suistainable status of Cirata Reservoir's management based on $y$ cageculture (\%) 
sekitar Waduk Cirata masih kuat tetapi karena banyak pendatang dari kota, adat istiadat tersebut menjadi longgar khususnya untuk generasi muda.

\section{KESIMPULAN DAN SARAN}

\section{Kesimpulan}

- Aspek ekologi $(22,29 \%)$ merupakan aspek yang paling lemah dalam keberlanjutan pengelolaan Waduk Cirata.

- Aspek sosial budaya (57,37\%) merupakan aspek terbesar sebagai modal utama dalam melakukan intervensi pada aspek lainnya yaitu aspek ekonomi (51,32\%); hukumkelembagaan $(40,16 \%)$, dan teknologi/ infrastruktur $(49,79 \%)$.

\section{Saran}

1) Untuk menuju keberlanjutan fungsi ekonomi dan ekologi maka perlu penataan dan pengaturan kembali terhadap kegiatan perikanan budidaya KJA, peternakan, pertanian dan industri di wilayah sekitar Waduk Cirata.

2) Peningkatan partisipasi stakeholder (penduduk di sekitar wilayah waduk, pembudidaya ikan, pengelola pabrik pakan ikan) dengan penyuluhan intensif oleh instansi terkait tentang pengelolaan Waduk Cirata berkelanjutan.

\section{DAFTAR ACUAN}

Badan Pengelola Waduk Cirata (BPWC). 2003. Laporan Pemantauan Kualitas Air Waduk Cirata. Bandung, $27 \mathrm{hlm}$.

Badan Pengelola Waduk Cirata (BPWC). 2003. Laporan Pemantauan Kualitas Air Waduk Cirata. Bandung, $36 \mathrm{hlm}$.

Garno, Y.S. 2002. Beban Pencemaran Limbah Perikanan Budidaya dan Yutrofikasi di
Perairan waduk pada DAS Citarum. P3TLBPPT. J. Teknik Lingkungan, 3: 112- 120.

Hassanshahi, H., Irvani, H., \& Kalantari, K. 2008. Analysis of Capital Assets of Natural Resources Management System in the Agricultural Production Cooperatives (APCs) in Fars Province, Iran. Australian J. of Basic and Applied Sciences, 2(4): 864- 871.

Krismono. 1999. Pengelolaan Lingkungan Budidaya Ikan di Keramba Jaring Apung. Warta Penelitian Perikanan Indonesia, 5: 15- 18.

MSMAS. 2009. DAS Citarum, Kondisi dan Rencana Penanganannya. http:// www.indonesiapower.co.id. html [11 juni 2011].

Mutiari, Y.L. 2005. Penegakkan Hukum Lingkungan: Sanksi Administrasi Menurut UU No. 23 tahun 1997 Tentang Pengelolaan Lingkungan Hidup di Sumatera Selatan. Simbur Cahaya, No. 27 Tahun X, 31 hlm.

Pinter, L., Hardi, P., \& Bartelmus, P. 2005. Indicators of Sustainable Development: Proposals for a Way Forward. Expert Group Meeting on Indicators of Sustainable Development, 13- 15 December. New York: United Nations Division for Sustainable Development, $61 \mathrm{pp}$.

Pitcher, T.J. \& Preischot, D. 2001. RAPFISH: A Rapid Appraisal Technique to Evaluate Sustainability Status of Fisheries. Fisheries Research, 49: 255- 270.

Prihadi, T.H. 2005. Pengelolaan waduk berbasis budidaya ikan secara lestari, pengelolaan sumberdaya alam dan lingkungan. Disertasi. Bogor: Program Pascasarjana, Institut Pertanian Bogor, $271 \mathrm{hlm}$.

Rammel, C., Stagl, S., \&Wilfing, H. 2007. Managing Complex Adaptive Systems - A CoevoIutionary Perspective on Natural Resource Management. Ecological Economics, 63: 921. 